DOI: $10.17951 / 1.2016 . X I V .1 .73$

A N N A LES

UNIVERSITATIS MARIAE CURIE-SKŁODOWSKA

LUBLIN - POLONIA

VOL. XIV, 1

SECTIO L

2016

Instytut Sztuk Pięknych UMCS

Piotr MajewsKi

\title{
Muzyka i malarstwo - poszukiwanie wspólnego gruntu na marginesie Partytur do baletu Sokrates Włodzimierza Pawlaka
}

Music and Painting: the Search for Common Ground on the Sidelines of The Scores for the Ballet Socrates by Włodzimierz Pawlak

Czy kiedykolwiek pozwolono płótnu wyśpiewać bardziej kapryśne melodie, bardziej niezwykty akord z tonów nowych, nieznanych, subtelnych, urzekajacych?

Charles Baudelaire

Przynajmniej od czasów romantyzmu istotnym obszarem relacji łączących sztuki dźwięku i obrazu były próby wykazania powinowactw strukturalno-formalnych pomiędzy poszczególnym sztukami. Na gruncie muzyki przyniosły one słynną koncepcję ,,świetlnego fortepianu” Aleksandra Skriabina, a w sztuce zainteresowania tego typu osiągnęły apogeum w nurtach malarstwa kolorystycznego i abstrakcji lirycznej, a także wpłynęły na metaforykę muzyczną w języku krytyki artystycznej. Obok sfery muzycznej ikonografii i imaginacyjnie wzbudzanych w obrazach odniesień audialnych, w sztukach wizualnych rozwinął się ponadto nurt synkretyczny, w którym doznania wzrokowe uzupełniane były o doznania dźwiękowe. Dzięki rozwojowi technik dźwiękowych i obrazowych nurt ten okazał się szczególnie płodny w sztuce współczesnej, jak też w kulturze popularnej. 
Również z tego powodu mariaże te bywały i bywają przedmiotem zainteresowania instytucji wystawienniczych, a dobrym tego przykładem na gruncie polskim w ostatnich latach może być wystawa Inwazja dźwięku przygotowana w 2009 roku przez Zachętę - Narodową Galerię Sztuki, poświęcona właśnie szeroko rozumianym związkom muzyczno-plastycznym w sztuce współczesnej ${ }^{1}$.

Cykl malarski Włodzimierza Pawlaka, objęty wspólnym tytułem Partytury do baletu Sokrates, jest jednym z bardziej wyrazistych przykładów dowodzących, że muzyczne inspiracje nie znikają ze współczesnego malarstwa. Wręcz przeciwnie, ich obecność świadczy o swoistej ciągłości idei powinowactwa sztuk, odsyłającej głęboko do romantycznych źródeł nowoczesności i współczesności. Cykl ten skłania więc do odświeżenia pytań o relacje malarsko-muzyczne, prowokuje do przypomnienia zarówno niektórych aspektów historii ich kształtowania, jak też pewnych założeń teoretycznych stojących u ich podstaw. Jako rozbudowany, realizowany konsekwentnie przez lata cykl malarski o tematyce muzycznej, jest też wyrazistym exemplum wpisującym się w szeroką problematykę badań nad związkami sztuki i muzyki prowadzonymi współcześnie².

\section{Malarskie partytury}

Kilkadziesiąt płócien Włodzimierz Pawlaka z cyklu Partytury do baletu Sokrates powstało w latach 2002-20083. Obrazy zawierają w sobie pewne motywy muzyczne, a ściślej - mieszczą w sobie element charakterystyczny dla zapisu nutowego. Jest to pojawiający się we wszystkich pracach motyw pięciolinii. $\mathrm{Na}$ niej muzyk umieszcza odpowiedniki dźwięków w postaci zapisu nutowego - ten uniwersalny alfabet dla wtajemniczonych, dzięki któremu można odczytać i wykonać każde utrwalone w ten sposób dzieło muzyczne. Tam, gdzie w zapisie nutowym są znaki różnych elementów muzycznych, w obrazach Włodzimierza Pawlaka są barwne plamy. Czy są one znakami dźwięków? Czy raczej ich wyobrażonymi odpowiednikami?

${ }^{1}$ Inwazja dźwięku. Muzyka i sztuki wizualne, kuratorzy: A. Morawińska, F. Quintin, 7 kwietnia - 2 sierpnia 2009, Zachęta - Narodowa Galeria Sztuki.

${ }^{2}$ Zob. Muzyka w sztukach wizualnych XIX-XXI wieku, 13-15 kwietnia 2011, Instytut Sztuki Polskiej Akademii Nauk, Warszawa, Konferencja naukowa zorganizowana przez Zakład Muzykologii IS PAN.

${ }^{3}$ Cykl pokazany został na wystawie Włodzimierz Pawlak. Partytury do baletu Sokrates, 14 czerwca - 7 lipca 2013, kurator: P. Majewski, Galeria Lipowa 13, Lubelskie Towarzystwo Zachęty Sztuk Pięknych. Niniejszy artykuł jest obszernym rozwinięciem wstępu do folderu tej wystawy. 
Z pewnością „zapis” malarza nie jest alfabetem konwencjonalnym (jak notacja muzyczna), tylko raczej pozostaje subiektywną kombinacją barw i gestów, za którą kryje się - jak można sądzić - przeżycie muzyczne. Dodajmy, że dzieło muzyczne Balet Sokrates faktycznie nie istnieje albo istnieje tylko w wyobraźni malarza. Jak zatem może spojrzeć muzyk na tego typu zapis? Czy tylko jak na impresję oddającą bliżej niesprecyzowane echo przeżycia muzycznego? Czy też dla muzyka o zdolnościach improwizacyjnych mogłyby te obrazy-partytury być punktem wyjścia eksperymentów z dźwiękowymi strukturami - odpowiednikami tych barwnych kompozycji? I na ile mogłaby tego typu improwizacja spełnić intencje partytury?

Pojawiająca się w tytule cyklu nazwa „partytura” sugeruje pewien kierunek interpretacji. Partytura bowiem - jak mówi definicja - jest notacyjnym zestawieniem wokalnych i instrumentalnych partii utworu muzycznego w celu przejrzystego utrwalenia dzieła muzycznego, które ułatwia orientację w dziele muzykom i publiczności śledzącej wykonanie z niej utworu muzycznego ${ }^{4}$. Partytura ma więc w sobie element prezentacyjny, wyrażony środkami graficznymi, czysto wizualnymi. Muzyczność partytury stanowi jej potencjalność. Z jednej strony rzeczywiste partytury są w pewnym stopniu nieme, ale w pewnym stopniu są intencjonalnie nasycone dźwiękami. Wprawny muzyk odsłuchuje je w myślach bez większego wysiłku. Ale czy w takim sensie można mówić o partyturach Pawlaka?

Notacja muzyczna tworzy pewien system znaków graficznych odzwierciedlających konstrukcję dzieła muzycznego. System ten, zanim przyjął formę znaną nam dzisiaj, dość burzliwie kształtował się przez długie stulecia. Zarazem w odniesieniu do muzyki nowoczesnej pojawiły się jego nowe, zmodyfikowane, często rozwinięte graficznie formy. Obrazy Pawlaka mogą kojarzyć się zarówno $\mathrm{z}$ archaicznymi systemami notacyjnymi, w których pojawiały się znaki pisma niemuzycznego, w tym znaki wielokolorowe, które odzwierciedlały w sposób ogólny schemat utworu będący podstawą do improwizacji. I przeciwnie, mogą one też kojarzyć się z nowymi formami zapisu (które wystąpiły w muzyce współczesnej w związku z rozwojem nowych technik kompozytorskich, takich jak np. aleatoryzm czy muzyka elektroniczna), a które dążą do utrwalenia i przekazania zjawisk muzycznych wykraczających poza możliwości tradycyjnego zapisu muzycznego. Najbardziej może trafna do porównań byłaby tutaj notacja aleatoryczna, w której kompozytor celowo niedokładnie określa obraz dźwiękowy kompozycji w partyturze, gdyż zakłada współdziałanie przy odtworzeniu utworu

\footnotetext{
${ }^{4}$ Partytura, [w:] Encyklopedia muzyki, drugie wydanie poprawione i rozszerzone, red. A. Chodkowski, Warszawa 2001, s. 670.
} 
muzycznego czynników przypadkowych lub działań losowych. Nawiasem mówiąc, czy malując Partytury Włodzimierz Pawlak nie podpisuje się przy okazji pod tezą, że w zasadzie notacja muzyczna nigdy nie zakłada precyzji wykonawczej i że każde wykonanie jest, przynajmniej w pewnym stopniu, przebiegiem aleatorycznym? Ale cykl Partytur prowokuje też inne pytania. Jak lokuje się on w historii poszukiwania powinowactw pomiędzy malarstwem i muzyką? I czy w ogóle muzykę można odzwierciedlić za pomocą znaków malarsko-rysunkowych? Pytanie tylko pozornie brzmi dziwnie, skoro pewna liczba artystów i teoretyków sztuki podejmowała się udzielić odpowiedzi twierdzącej. Z pewnością nie można zobaczyć muzyki wprost, tak jak nie można usłyszeć barw, choć istnieje - potwierdzone naukowo, lecz zarezerwowane dla nielicznych - zjawisko synestezji, barwnego widzenia. Ale już każdy może zobaczyć pewne elementy charakterystyczne dla struktury działa muzycznego, jak na przykład rytm. Można wszak zobaczyć rytm kolumn w portyku, co wskazywałoby na to, że romantyczna idea korespondencji sztuk ma podstawy empiryczne.

\section{Wyimki z koncepcji korespondencji sztuk}

Już XIX wiek przynosi wyjątkowe nagromadzenie prób powiązania sztuk, a w szczególności malarstwa i muzyki. Wystarczy porównać objętości opracowań monograficznych poświęconych muzyczno-plastycznym relacjom dotyczącym różnych epok. Przykładu dostarczają opracowania Petera Vergo. Jego książka pt. That Divine Order, która obejmuje blisko 2 tysiące lat związków muzyki i sztuki, od czasów Konfucjusza do europejskiego oświecenia, liczy około 300 stron $^{5}$. Wydana kilka lat później druga książka tego autora na ten temat, pt. Music of Painting, skoncentrowana na czasach modernizmu, liczy tych stron blisko $400^{6}$. Sam autor podkreśla, że powody tego objętościowego rozziewu są przynajmniej dwa. Z jednej strony, liczba źródeł i dokumentów dotyczących nowszej historii jest znacznie większa niż zasoby dowodowe odnoszące się do odleglejszej przeszłości. Ale, co istotniejsze, te nowe czasy, nowoczesność właśnie, przynosi, co podkreśla Vergo, niezwykły entuzjazm porównywania różnych sztuk, widoczny u XIX- i XX-wiecznych teoretyków, muzyków i artystów ${ }^{7}$. Wielu z nich poświęciło znaczną ilość czasu nie tylko po to, aby przełamać bariery dzielące sztuki, ale też po to, aby odnaleźć korzyści stąd płynące (które niekiedy okazywały się

\footnotetext{
${ }^{5}$ P. Vergo, That Divine Order, London 2005.

${ }^{6}$ Idem, Music of Painting: Music, Modernism and the Visual Arts from the Romantics to John Cage, London 2012.

${ }^{7}$ Ibid., s. 6.
} 
iluzoryczne). Stawiając pytanie o powody tej intensywnej aktywności, autor odnajduje odpowiedź w intelektualnych imperatywach, które były dla wielu nowoczesnych artystów - szczególnie malarzy - motorem napędzającym spojrzenie na muzykę jako na źródło inspiracji.

Punktem wyjścia rozważań autor uczynił proklamowanie przez Richarda Wagnera idei „dzieła sztuki przyszłości”, Gesamtkunstwerk, a punktem dojścia analizy jest twórczość Johna Cage’a. Przy czym Peter Vergo skupia uwagę na badaniu relacji pomiędzy sztukami wizualnymi a muzyką, sytuując ją w opozycji do innych działań dźwiękotwórczych i hałasu. W jego opinii muzyka, dźwięk i hałas to trzy różne fenomeny audialne, nawet jeśli granice pomiędzy nimi są czasami płynne. Instalacje multimedialne, video art i inne zwłaszcza intermedialne nurty sztuki współczesnej są pełne tego typu inkorporacji, które trzeba wyodrębnić jako inną, nową historię. Autora interesują natomiast relacje pomiędzy sztuką i muzyką, w których pojawia się rodzaj przekładu języka jednego medium artystycznego na język medium drugiego, jak w utworach muzycznych Modesta Musorgskiego Obrazki z wystawy albo w słynnym obrazie Františka Kupki Amorpha: Fugue in Two Colours, w malowanych fugach i sonatach Mikalojusa Čiurlionisa czy w graficznych i rzeźbiarskich translacjach fragmentów muzycznych notacji wykonanych przez Henrika Neugeborena i Paula Klee.

Niewątpliwie poszukiwanie tego typu związków w owym czasie pobudzało także namysł teoretyczny i stymulowało rozwój muzycznej metaforyki w języku krytyki artystycznej. W tym kontekście warto przywołać uwagi na temat „muzyczności” malarstwa w refleksji teoretycznej Eugène Delacroix, które odzwierciedlają ideę correspondance des arts, przyznającą sztukom niewerbalnym - malarstwu i muzyce - rolę najwłaściwszych środków wyrazu dla subiektywnej ekspresji, najlepiej oddającą niewyrażalne - le vague. W Dziennikach pod datą 16 maja 1857 notował:

„Voltaire nazywa pięknem to, co winno urzekać umysł i zmysły. Motyw muzyczny wykonany na instrumencie, który na jeden tylko sposób przemawia do zmysłów, może działać na wyobraźnię, ale połączenie instrumentów różnych i o różnej dźwięczności da więcej siły wrażeniu. Po co tedy używać raz fletu, innym razem trąbki? Flet przywiedzie na myśl spotkanie kochanków, trąbka tryumf wojownika i tak dalej. Nawet w muzyce fortepianowej po co używać raz tonów stłumionych, to znów tonów pełnych, jeśli nie dla wzmocnienia wyrażanej myśli? Nie pochwalam dźwięczności zastępującej myśl; a jednak nie da się zaprzeczyć, że pewne zestawienia tonów niezależnie od wyrazu są przyjemnością dla zmysłów.

${ }^{8}$ Ibidem. 
Podobnie jest z malarstwem: prosta kreska wyraża mniej i mniej się podoba niż rysunek oddający cienie i światła. Rysunek z kolei mniej mówi niż obraz: mam wciąż na myśli obraz doprowadzony do tego stopnia harmonii, kiedy rysunek i kolor łączą się w jedną całość. Warto pamiętać tego starożytnego malarza, który pokazując obraz przedstawiający wojownika kazał jednocześnie grać fanfarę trębaczowi ukrytemu za zasłoną"”.

Charles Baudelaire w tym czasie pisał o malarstwie (nawiasem mówiąc, szczególnie Delacroix, którego wielbił), nasycając język bogactwem terminów muzycznych. Oto opis sceny zachodzącego słońca:

„Gdy wielkie ognisko zstępuje do wód, ze wszystkich stron rozbrzmiewają czerwone fanfary; krwawa harmonia wybucha na widnokręgu i zieleń wzbogaca się purpurą. Lecz wkrótce szerokie i błękitne cienie w miarowym rytmie zaczynają pędzić przed sobą tony pomarańczowe i lekko różowe, które są jak dalekie i słabnące echo światła. Ta wielka symfonia dnia, wieczna odmiana symfonii dnia wczorajszego, to następstwo melodii, gdzie zmienność płynie z nieskończoności, i złożony hymn nazywa się kolorem. W kolorze odnajdujemy harmonię, melodię i kontrapunkt" ${ }^{10}$.

Z kolei niektóre uwagi Waltera Patera z eseju Szkoła Giorgione z 1877 roku świadczą o tym, że muzyka urastała w owym czasie do rangi powszechnego wzoru dla innych sztuk:

„Lecz chociaż każda sztuka ma swój własny porządek wrażeń i nieprzekładalny czar, a ścisłe rozpoznanie istotnych różnic pomiędzy różnymi jej rodzajami jest początkiem krytyki estetycznej; można spostrzec, że w szczególnym sposobie traktowania danego materiału, każda sztuka łączy się z inną, co niemieccy krytycy nazywają Anders-streben - częściowym odchodzeniem od własnych ograniczeń, dzięki któremu różne rodzaje sztuki mogą nie zajmować swoich miejsc, ale wzajemnie obdarzać się nowymi siłami. [...] wszystkie sztuki dążą do zasady muzyki; gdyż muzyka jest typem sztuki, sztuką idealną i doskonałą, przedmiotem owego Anders-streben wszelkich jej rodzajów, tego, co jest artystyczne, lub ma swój udział w jakościach artystycznych. Każda sztuka bezustannie usiłuje zaistnieć na sposób muzyki" ${ }^{11}$.

${ }^{9}$ E. Delacroix, Dzienniki, [w:] Teoretycy, artyści i krytycy o sztuce 1700-1870, przekł. J. Guze, J. Hartwig, wybór przedmowa i komentarze E. Grabska, M. Poprzęcka, Warszawa 1989, s. 414.

${ }^{10}$ Ch. Baudelaire, Salon 1846. III. O kolorze, [w:] ibid., przekł. J. Guze, s. 432.

${ }^{11}$ W. Pater, Renesans. Rozważania o sztuce i poezji, Warszawa 1998, s. 102-103. 
Kończący cytowaną wypowiedź passus jest najbardziej znanym stwierdzeniem estetycznym Patera. Odczytywany jest on dwojako: jako wyraz dążenia do autonomizacji jakości formalnych w sztuce, a także jako jedno z fundamentalnych przekonań kształtującej się w tym czasie estetyki modernistycznej ${ }^{12}$.

\section{Malarstwo abstrakcyjne, dodekafonia i jazz}

Wassily Kandinsky cytował właśnie Delacroix w swoim traktacie $O$ pierwiastku duchowym w sztuce, gdy wyrażał przekonanie, że ,język form i kolorów" w malarstwie jest wystarczający, aby komunikować znaczenie dla widza. Casus ten jest szczególnie ciekawy, gdyż to właśnie u Kandinsky’ego pojawiło się silnie podkreślane porównywanie abstrakcji malarskiej do abstrakcyjnego języka muzyki. Wypada przypomnieć słowa artysty zapisane we wspomnianym traktacie, w których - nawiasem mówiąc - pobrzmiewają echa przekonań Patera sprzed ponad trzech dekad o jednoczeniu sztuk:

„W ten sposób różne gałęzie sztuki próbują wyrazić to, co jedynie one potrafią i środkami dla każdej z nich najbardziej właściwymi. Pomimo naturalnych pomiędzy nimi różnic, a może dzięki nim, nigdy jeszcze rozmaite sztuki nie były tak blisko siebie, jak właśnie dziś, w czasach duchowej przemiany" 13 .

Jak wiadomo traktat Kandinsky'ego zawiera wiele analiz i spostrzeżeń dotyczących wzajemnych relacji pomiędzy muzyką i malarstwem, świadczących o wszechstronnym zainteresowaniu malarza w tym zakresie. Dotyczą one: zjawiska barwnego słyszenia i malarskiego widzenia dźwięków (synestezji); powinowactwa oddziaływania dźwięku i koloru wprost na duszę, które Kandinsky wyraża za pomocą pięknej metafory: „Kolor jest klawiszem. Oko jest młoteczkiem. Duch zaś wielostrunnym fortepianem"14. W zakończeniu tego dziełka teoretycznego pojawia się też opis kompozycji malarskich w kategoriach terminów muzycznych. Kandinsky wyróżnia: kompozycję melodyczną (prostą, zdominowaną przez jedną wybijającą się formę), symfoniczną (złożoną, skomplikowaną, o ukrytej dominancie), omawia też kompozycję rytmiczną. Własne poszukiwania

${ }^{12}$ A. Eastham, Walter Pater's Acoustic Space: ,, the School of Giorgione”, Dionysian ,, anders-streben”, and the Politics of Soundscape, ,The Yearbook of English Studies” 2010, nr 40 (1/2), s. 196-216. http://www.jstor.org/stable/41059788.

${ }^{13}$ W. Kandinsky, O duchowości w sztuce, przekł. S. Fijałkowski, Łódź 1996, s. 53.

${ }^{14}$ Ibid., s. 62. 
dzieli na trzy typy inspiracji. Są to: Impresje (wrażenia z natury), Improwizacje (wrażenia wewnętrzne), Kompozycje (wypowiedzi uporządkowanie, przemyślane, zracjonalizowane).

Nie mniej interesująca jest pewna zbieżność chronologiczna przełomów w języku sztuki Kandinsky'ego i Arnolda Schönberga, bardzo dokładnie opracowana w badaniach szczegółowych, prowadzonych począwszy od opublikowania korespondencji pomiędzy twórcami w latach 80 . XX wieku ${ }^{15}$. Obaj artyści - malarz i muzyk - przyjaźnili się ze sobą, korespondowali, prowadzili dialog intelektualny. Obaj rozwijali zainteresowania przekraczające ich własne dziedziny. Schönberg zajmował się malarstwem, Kandinsky natomiast poezją. Około 1908 roku u Kandinsky'ego pojawia się, obok intensyfikacji barw, zacieranie granic między abstrakcyjnym a figuratywnym charakterem obrazu. Z kolei Schönberg, w trzecim z pięciu Orchesterstücke, op. 16, z 1906 roku, po raz pierwszy podejmuje próbę zastosowania wymyślonej przez siebie techniki Klangfarbenmelodie, polegającej na zastąpieniu melodii interwałowej, kolorystyką instrumentalną, porównywalną do techniki pointylizmu, jako że melodia nie jest prowadzona przez jeden głos, lecz jest rozdzielona pomiędzy kilka instrumentów ${ }^{16}$. Jak wiadomo, dalsze eksperymenty prowadziły kompozytora poprzez przełamanie tonalności, dominację ekspresji i akcentowanie dysonansu do rozwiązań dodekafonicznych.

Zainteresowania Kandinsky'ego ideą powiązania muzyki i sztuk wizualnych przyniosły także eksperyment sceniczny zrealizowany w Dessau, w ramach szkoły Bauhaus ${ }^{17}$. Nawiasem mówiąc, w Bauhausie przekonanie o absolutnej sile muzyki podzielali także Paul Klee i Lyonel Feininger. W 1928 roku Kandinsky podjął się zrealizowania swojego zamysłu „sztuki totalnej”, niewątpliwie nawiązując do wagneriańskiego Gesamtkunstwerk, przygotowując sceniczne widowisko, które polegało na wykonaniu utworu Modesta Musorgsky'ego Obrazki z wystawy ${ }^{18}$ na tle plastycznej dekoracji, złożonej z 16 ruchomych animacji obrazowych, przygotowanych według własnych szkiców artysty. Cykl obrazów

${ }^{15}$ Arnold Schoenberg, Wassily Kandinsky: letters, pictures, and documents, by J. Hahl-Koch and J. C. Crawford, London 1984; zob. też: S. Zabieglińska, Schönberg i Kandinsky: porównanie postaw estetycznych i środków wyrazu, praca doktorska, promotor: Z. Skowron, 2011.

${ }^{16}$ Klangfarbenmelodie, [w:] Encyklopedia muzyki..., s. 437.

${ }^{17} \mathrm{Na}$ temat muzyki w Bauhausie zob. C. Jewitt, Music at the Bauhaus, 1919-1933, „Tempo” (New Series) 2000, No. 213, pp. 5-11. URL: http://www.jstor.org/stable/946540.

${ }^{18}$ Obrazki z wystawy Modesta Musorgsky'ego to znany przykład dzieła muzycznego zainspirowanego dziełem plastycznym.

W 1874 roku Musorgsky skomponował miniatury fortepianowe do rysunków i akwarel jego przyjaciela Victora Hartmana. Tych utworów jest 10. Każdy z nich opisuje inny obraz o charakterze przedstawiającym. Niektóre z nich łączy dodatkowa miniatura zatytułowana Promenade, która pojawia się w 6 wariacjach. 
składał się z form geometrycznych, kolorów, linii i barwnych świateł, przeplatanych scenkami przedstawiającymi, ściśle zsynchronizowanymi z muzyką. Same elementy tej scenografii nie zachowały się, nie ma też zapisu filmowego tamtego wydarzenia. Pozostały zaś akwarelowe szkice Kandinsky’ego, które przechowywane są w zbiorach Centre Pompidou w Paryżu. W 2010 roku w paryskim Cité de la Musique miała miejsce premiera widowiska według pierwotnego zamysłu Kandinsky'ego w wykonaniu pianisty Mikhaila Rudy'ego. Tak powstała nowa wersja tego przedsięwzięcia, wykorzystująca projekcje przygotowane w nowych technologiach na kanwie historycznych szkiców Kandinsky'ego.

Malarze abstrakcji szczególnie chętnie sięgali (i czynią to po dzień dzisiejszy) po muzyczne inspiracje. Znany przykład przynosi twórczość Pieta Mondriana, gdyż dotyczy nowego rodzaju muzyki - jazzu, traktowanego przez tego artystę jako muzyka nowoczesna. Przy czym określenie „nowy rodzaj muzyki” trzeba traktować umownie, gdyż faktycznie w momencie, gdy Mondrian podjął ten temat, ów gatunek muzyczny miał już blisko 40-letnią historię.

Wkrótce po przyjeździe do Nowego Jorku w 1940 roku holenderski artysta maluje dwa słynne obrazy: Broadway Boogie-Woogie (1942) i Victory Boogie-Woogie (1943), zupełnie inne niż dotychczasowe, konsekwentnie realizujące od lat 20. założenia programowe neoplastycyzmu. Co prawda, także te obrazy mają strukturę kompozycyjną opartą na wertykalnych i horyzontalnych podziałach, ale, inaczej niż dotychczas, nie tworzą ich czarne linie wydzielające pola zapełniane podstawowymi kolorami, lecz wykreślają je drobne barwne kwadraty i prostokąty, głównie żółte (ale też niebieskie, czerwone i szaro-białe), które układają się w pasy podziału pola obrazowego. Są one rytmiczne, choć nieregularne, ale dynamiczne i wywołują wrażenie ruchu. Można w nich widzieć nawiązanie do siatki ulic Manhattanu, okien drapaczy chmur lub świateł samochodów, jak wskazywało wielu komentatorów ${ }^{19}$. Tytuły jednak sugerują coś innego: zainteresowanie stylem jazzu, którym w owym czasie przesiąknięty był Nowy Jork. Kiedy Mondrian przybywa do Nowego Jorku, miasto to jest opanowane przez modny wówczas boogie-woogie - jazzowy styl fortepianowy wywodzący się $\mathrm{z}$ bluesa o charakterystycznym żywiołowym rytmie wykonywanym za pomocą basów lewą ręką, który wprowadza szybki puls prowokujący do dynamicznego tańca. W wypowiedzi Mondriana z około 1943 r. odnaleźć można następującą deklarację:

\footnotetext{
${ }^{19} \mathrm{Na}$ temat interpretacji nowojorskich obrazów Pieta Mondriana zob. np. H. Cooper, Mondrian, Hegel, Boogie, „October” 1998, Vol. 84, pp. 118-142. DOI: 10.2307/779211, URL: http://www. jstor.org/stable/779211.
} 
„Prawdziwe boogie-woogie odbieram jako pokrewne wobec mojego malarstwa: destrukcja melodii jest ekwiwalentem destrukcji wyglądów naturalnych, a konstrukcja - poprzez stałą grę czystych środków - wprowadza dynamiczny rytm" 20 .

Zatem dominujący nad melodią rytm w muzyce jazzowej Mondrian potraktował jako odpowiednik abstrakcyjnych form w jego malarstwie, a w drugoplanowości melodyki w muzyce jazzowej widział odpowiednik nieobecności wyglądów naturalnych w obrazach.

\section{Włodzimierz Pawlak - spadkobierca romantycznego parnasu?}

Choć Włodzimierz Pawlak jest malarzem a nie muzykiem, warto podkreślić fakt pasji muzycznej artysty, umiejętność gry na fortepianie, jak też nieustanne zasłuchanie artysty w muzyce. Nasuwa się w tym miejscu na myśl skojarzenie $\mathrm{z}$ przysłowiowymi le violon d'Ingres - artysta posiada zamiłowanie w kierunku nieuprawianym zawodowo, co jednak pozostaje nie bez wpływu na malarstwo. To szczególne podejście do muzyki malarz dzieli z wieloma innymi artystami obcymi i polskimi, którzy podejmowali tematykę muzyczną w sztukach wizualnych. Obok wspomnianych malarzy-muzyków Čiurlionisa i Klee, na gruncie polskim warto - za Jackiem Szerszenowiczem - przywołać Wojciecha Weissa, który już na przełomie XIX i XX wieku podjął próbę skorelowania skal muzycznych i układów harmonicznych ze skalą i harmonią kolorystyczną ${ }^{21}$. Szerszenowicz określa ich mianem artystów „reprezentujących tendencje transmediane”. Pisze, że: „Można przyjąć założenie, że terminologia muzyczna - przeniesiona w obszar wyobraźni malarskiej - nie jest traktowana przez nich w sposób li tylko metaforyczny, lecz denotuje rzeczywiste cechy muzyczne uobecnione w dziele plastycznym" 22 .

Sam motyw partytury jako zadanie plastyczne pojawia się w rozmaitych wersjach w historii sztuki nowoczesnej i współczesnej. Ciekawy przykład omawia Maciej H. Zdanowicz, przywołując twórczość Władysława Szpakowskiego, któ-

${ }^{20}$ P. Mondrian, Statement, ca. 1943, [w:] Theories of Modern Art: A Source Book by Artists and Critics, by H. B. Chipp, P. Selz, J. C. Taylor, Berkeley and Los Angeles 1968, s. 364.

${ }^{21}$ J. Szerszenowicz, Etiudy transmedialne w szkicach pedagogicznych Paula Klee, [w:] Muzyka w sztukach wizualnych XIX-XXI wieku (Ikonografia muzyczna. Studia i materiały, t. 2), red. Jolanta Guzy-Pasiak, Warszawa 2013, s. 171-172. Aspekty muzyczne w twórczości plastycznej autor omawia szerzej w opracowaniu Inspiracje plastyczne w muzyce, Łódź 2012 [wyd. drugie], s. 505-574.

${ }^{22}$ Ibid., s. 173. 
ry już w swych wczesnych szkicach z początku XX wieku podejmował próby utrwalania materiału dźwiękowego za pomocą języka graficznego o charakterze

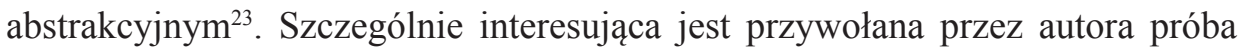
przeniesienia graficznego zapisu Szpakowskiego w sferę wykonania muzycznego, którą podjął w 1992 roku (blisko 20 lat po śmierci malarza) Zbigniew Bargielski, traktując wyjściowe szkice w duchu interpretacji aleatorycznej. Oprócz prac Szpakowskiego, autor analizuje także inne przykłady tworzenia graficznych partytur. Wśród analizowanych przykładów znalazły się koncepcje Zofii Stryjeńskiej, Romany Hałat, Janiny Kraupe-Świderskiej, Wojciecha Krzywobłockiego, Antoniego Haski i Krzysztofa Zarębskiego (jako przykład partytury użytej do wykonania performance'u).$^{24}$ Wszystkie te przykłady autor traktuje jako jeden z modeli plastycznej interpretacji muzyki w czasach nowoczesności, zgodnie z wykładnią Christophera Coxa.

W niewielkim, ale syntetycznym artykule Wizualne dźwięki: o partyturach graficznych Cox omówił przykłady niekonwencjonalnych notacji muzyki opracowywanych nie tyle przez malarzy, ile przez muzyków ${ }^{25}$. Zwrócił więc uwagę na odmianę eksperymentalną we współczesnej notacji muzycznej, którą określił właśnie jako „graficzną partyturę", a która, z jednej strony, ma korzenie w fascynacjach neoawangardy lat 50. i 60. XX wieku ideą intermediów, $\mathrm{z}$ drugiej - w improwizacyjnym charakterze muzyki jazzowej. Rozwój tego typu nowych sposobów zapisu sztuki dźwięku autor upatrywał więc w przemianach samej muzyki, której eksperymentalny charakter pociągnął za sobą także nowe sposoby graficznego ujęcia dzieła muzycznego. Za przykłady posłużyły mu dzieła takich reprezentantów muzyki eksperymentalnej, jak Karlheinz Stockhausen i John Cage. Cechą tego typu działań jest nacisk położony na aspekty improwizacyjne, zarówno w muzyce, jak i w jej graficznym odpowiedniku. Autor podkreślił też cechy tego typu zapisu oraz jego konsekwencje dla praktyki wykonawczej. Odwołując się do przykładu Anthony'ego Braxtona, który posługiwał się graficzną partyturą, Cox uznał, że miała być ona narzędziem ,uporządkowania dźwiękowego chaosu free

${ }^{23}$ M. H. Zdanowicz, Muzyka w sztukach wizualnych - koncepcje i rozwiazania, [w:] Muzyka w sztukach wizualnych, s. 158-160.

${ }^{24}$ Przywołany przez Macieja H. Zdanowicza przykład partytury jako punktu wyjścia performance'u w działaniach Krzysztofa Zarębskiego z 1975 roku wpisuje się w swoistą tradycję traktowania partytury jako instrukcji wykonawczej na gruncie sztuki happeningu oraz w teatrze eksperymentalnym. Na przykład partyturami posługiwali się wcześniej Tadeusz Kantor i Jerzy Grotowski.

${ }^{25}$ Ch. Cox, Wizualne dźwięki: o partyturach graficznych, [w:] Kultura dźwięku. Teksty o muzyce nowoczesnej, wybór i red. Ch. Cox, D. Warner, przekł. S. Wieczorek, Gdańsk 2010, s. 240-242. 
jazzu oraz zapewnienia zbiorowej improwizacji medytacyjnego centrum" ${ }^{26}$. Autor podkreślił, że tego typu zapis jest mało konkretny, daje jedynie ogólne wskazówki wykonawcze. Z jednej więc strony prawdopodobieństwo podobnego wykonania zapisanej w formie graficznej partytury jest znikome, $\mathrm{z}$ drugiej jednak - podsumował Cox - „wykonania kompozycji graficznych są zazwyczaj przestrzenne i intrygujące, pełne osobliwych dźwięków unoszących się wokół, niczym pociągnięcia pędzla malarzy akcjonistów i znaki mistrzów kaligrafii” ${ }^{27}$.

Sądzić można, że w cyklu obrazów Partytury do baletu Sokrates Włodzimierzowi Pawlakowi nie chodziło o uchwytną analogię z konkretnym muzycznym systemem notacyjnym, czy to wykorzystującym w przeszłości barwy, czy to eksperymentalnie rozwijanym we współczesności, ale raczej malarz zabiegał o ogólną sugestię zapisu relacji, napięć, powiązań elementów rozgrywających się w polu obrazowym, traktowanym tutaj jako ogólny obraz utworu muzycznego. Obrazy jawią się raczej jako propozycja barwnego i ekspresyjnego kodu abstrakcyjnego do odczytania $\mathrm{w}$ kategoriach improwizacji, a więc jedynie w stopniu przybliżonym, jako punkt wyjścia pobudzenia muzycznej imaginacji. Przy czym w poszczególnych obrazach malarz odwołuje się do najogólniejszych cech muzycznej ekspresji. Jedne „partytury” są lekkie, z niewielką liczbą znaków - plam barwnych, inne gęstnieją ciężkimi materiami malarskimi, nagromadzeniem barwnych tonów, kumulacją współbrzmień i dysonansów, w jeszcze innych plamy barwne rozlewają się po polu obrazowym, przywołując akustyczne skojarzenie z bardziej gwałtownymi rezultatami brzmieniowymi. Sporo tutaj niekontrolowanych emocji, wydawałoby się spontanicznych wybuchów euforycznej reakcji, której ucieleśnieniem są układy swobodnie traktowanych barwnych plam przypominających momentami niemal malarstwo gestu, ale, w kontekście konsekwentnie obecnej w tle pięciolinii, wzbudzających skojarzenia dźwiękowe - raczej dynamiczne i bogate w instrumentację niż spokojne i jednotonowe.

Wyjątkowość tego cyklu polega na dominacji koloru w notacji muzycznej. W przeciwieństwie do przywoływanych przykładów „partytur graficznych” w obrazach Włodzimierza Pawlaka elementy graficzne sprowadzone są do niezbędnego minimum, w zasadzie pozostaje nim jedynie regularny rysunek pięciolinii. Głównym impulsem wykonawczym (zakładając, że doszłoby do eksperymentalnego wykonania partytur) jest w tym wypadku kolor, który otwiera horyzont hipotetycznej muzycznej kreacji. Jego nagromadzenie i „wyraz” stanowią impuls do jego odczytania. Zgodnie ze „wskazówkami”, które podsuwa

\footnotetext{
${ }^{26}$ Ibid., s. 241.

${ }^{27}$ Ibid., s. 242.
} 
sama forma barwnych plam, przebiegałoby ono na osiach: cicho - głośno, wolno - szybko, spokojnie - dynamicznie. Partytury są obrazami malarskimi, można by powiedzieć „obrazami muzyki”, ale nie można wykluczyć ich potencjalności wykonawczej, czysto muzycznej. Prowokują nazwą i obecnością pięciolinii do wykonawczego eksperymentu o charakterze muzycznej improwizacji. Jednak w przypadku takiej próby wszelkie szczegóły (łącznie z instrumentarium) musiałby konkretyzować sam muzyk (lub muzycy). W tym sensie Partytury do baletu Sokrates pozostają przykładem „dzieła otwartego”, którego muzyczna konkretyzacja jest potencjalnie wielokierunkowa, można nawet dodać - potencjalnie niepowtarzalna, jedyna w sobie. Zarazem wszystkie prace z cyklu pozostają dziełami sztuki malarskiej samymi w swoim rodzaju. Ich funkcja nie sprowadza się do użytkowego zastosowania w praktyce muzycznej, lecz stanowią one zespół wartości malarskich, który łączy się w wyobrażonym uniwersum ze światem muzycznego kolorytu dźwięków, harmonii i nastrojów.

Przy całej umowności i niepewności porównań malarstwa i muzyki warto zapamiętać poszukiwanie powinowactwa i związków malarsko-muzycznych w kręgu zainteresowań Włodzimierza Pawlaka. Sam autor traktuje te obrazy jako kontrapunkt - powstały niejako z potrzeby reakcji na muzykę. To dość - nazwijmy go - prywatny, osobisty zestaw obrazów, a zarazem mniej znany obszar zainteresowań współtwórcy Gruppy. Z drugiej strony cykl ten, aktualizując pytanie o korespondencję sztuk, świadczy o tym, że idea ta - jedna z najbardziej wyrafinowanych w teorii sztuki, tak ożywiająca malarstwo Delacroix, jak też jego myśl teoretyczną o malarstwie, tak inspirująca Baudelaire'a do nasycania języka krytyki artystycznej terminami muzycznymi - nie wyczerpała się wraz z Kandinskym, Klee czy Mondrianem i jego muzycznymi boogie-woogies, lecz pozostaje żywa. Jest żywa tam, gdzie malarska praktyka spotyka się z jej teoretycznym pogłębieniem i czystym umiłowaniem muzyki, a w tym właśnie miejscu - pośród nielicznych już dzisiaj spadkobierców romantycznego parnasu - odnaleźć można Włodzimierza Pawlaka.

Wpisując się w nowe, współczesne oblicza łączenia muzyki i plastyki, omawiany cykl zajmuje na tym gruncie miejsce osobne i szczególne. Na tle długiej postromantycznej tradycji korespondencji sztuk może jawić się jako jej postmodernistyczny pastisz, ale też może prowokować pytanie o rangę jej aktualizacji w obliczu polimorficznej, rozedrganej i wciąż na nowo definiowanej kultury wizualnej dnia dzisiejszego. 


\section{SUMMARY}

The article undertakes the issue of the relationship between painting and music. The analysis of an extensive painting cycle by Włodzimierz Pawlak, titled The Scores for the Ballet Socrates (2002-2008), is the starting point. The motif of musical staves applied by the painter is common to all the images of this cycle. In the individual images there also appear color spots, painted in the type of "hot abstraction", forming diverse expressive effects, which give the images the nature of the recording of emotions associated with the experience of music.

The article presents some aspects of musical fascinations in the paintings of selected artists who represent the tradition of modernism, especially connected with international abstraction (Kandinsky, Mondrian), and Polish modern painters (Wojciech Weiss, Władysław Szpakowski). The author also draws attention to the presence in the dictionary of art theory and art criticism of musical terms, referring to the classical authors such as Delacroix, Baudelaire and Pater. Consequently, the author looks at the "musical" painting cycle of Włodzimierz Pawlak as an example of contemporary continuation of romantic aesthetic ideals, pointing to their ahistorical, endless potential. 
Pobrane z czasopisma Annales L - Artes http://artes.annales.umcs.pl Data: 26/04/2023 11:30:11

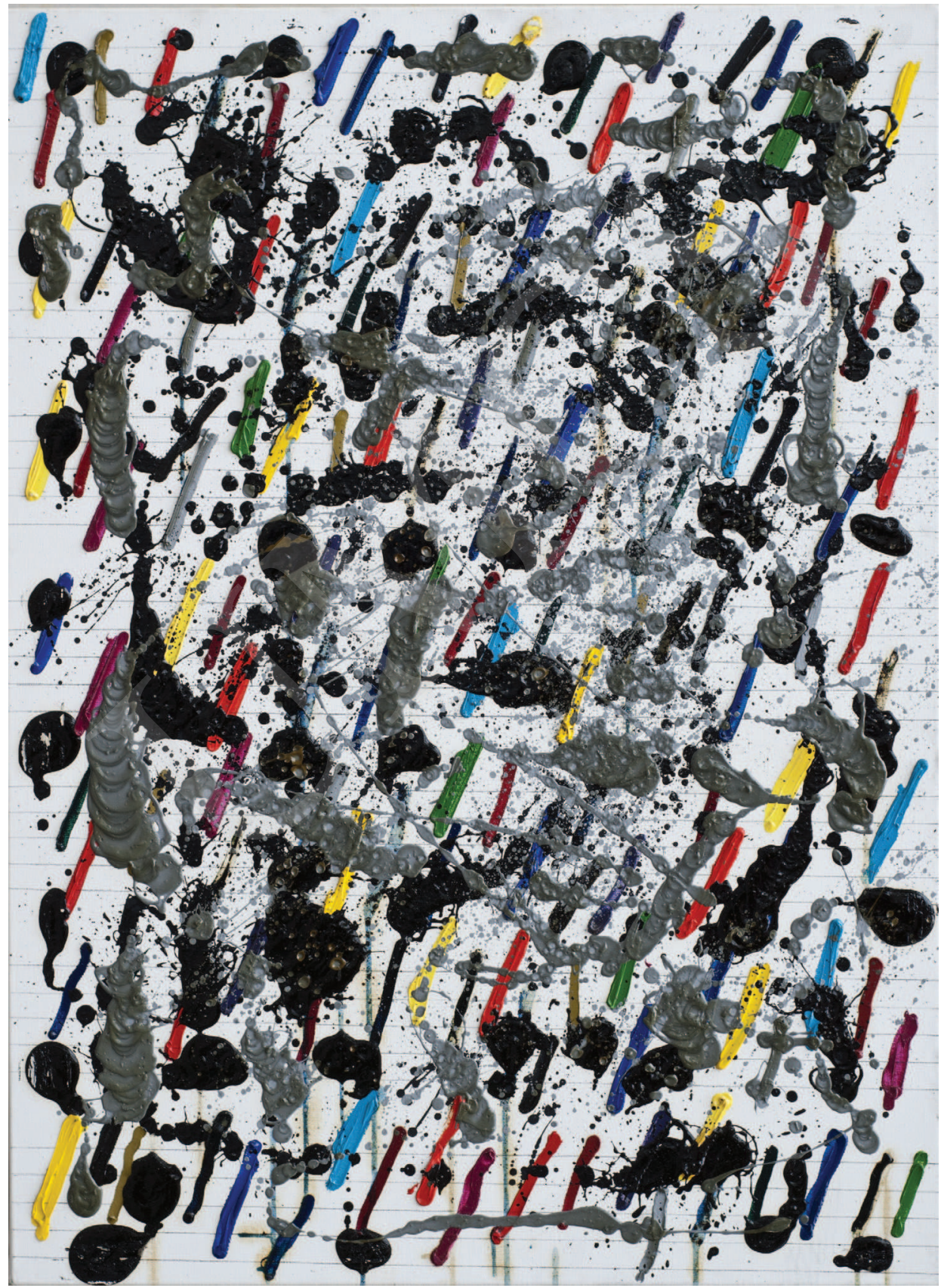

Ilustracja 1. W. Pawlak, Partytura do baletu Sokrates III, 2003, 73x100 cm, fot. K. Kuzko 
Pobrane z czasopisma Annales L - Artes http://artes.annales.umcs.pl Data: 26/04/2023 11:30:11

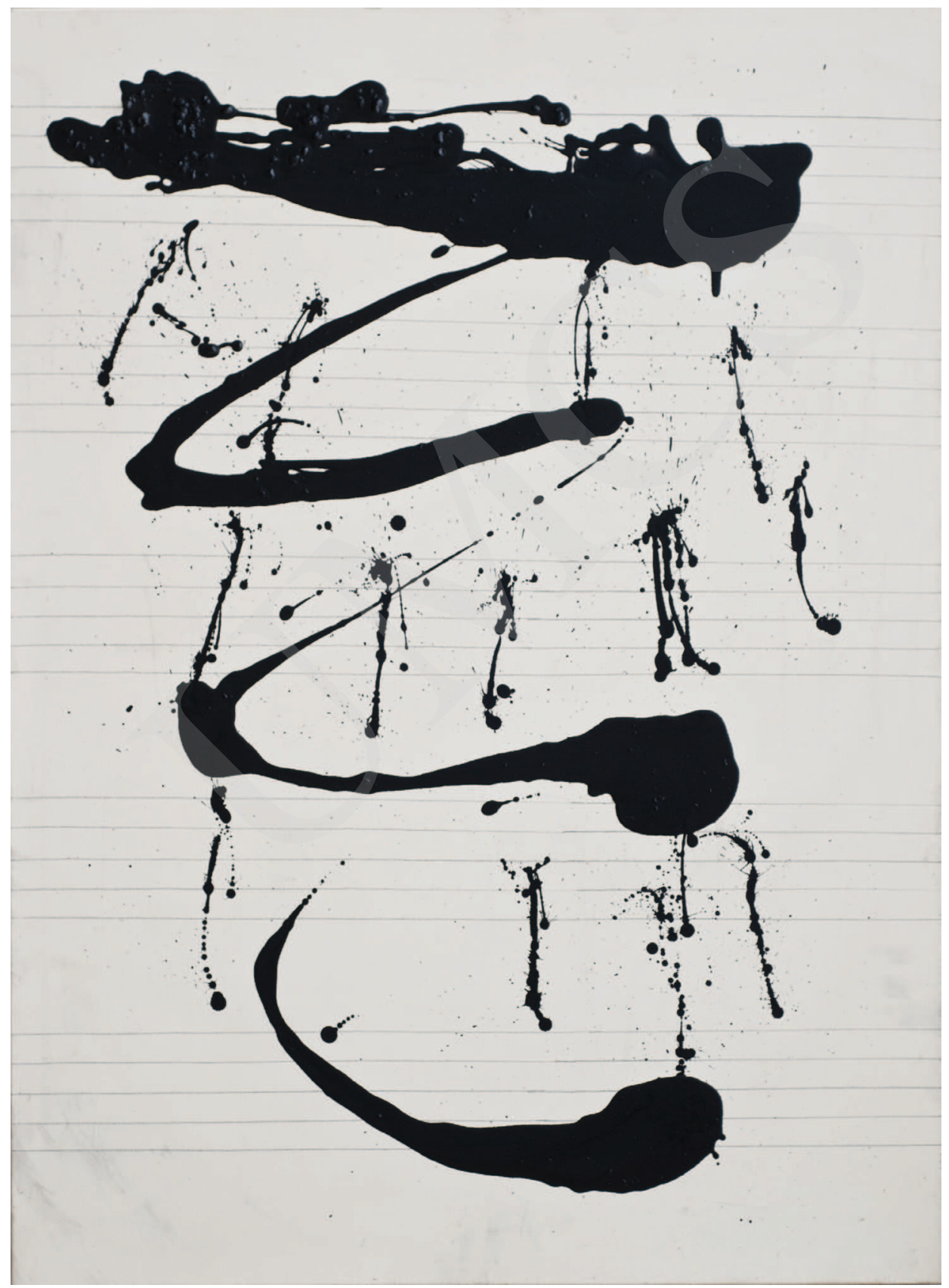

Ilustracja 2. W. Pawlak, Partytura do baletu Sokrates XXI, 2004, 73x100 cm, fot. K. Kuzko 
Pobrane z czasopisma Annales L - Artes http://artes.annales.umcs.pl

Data: 26/04/2023 11:30:11

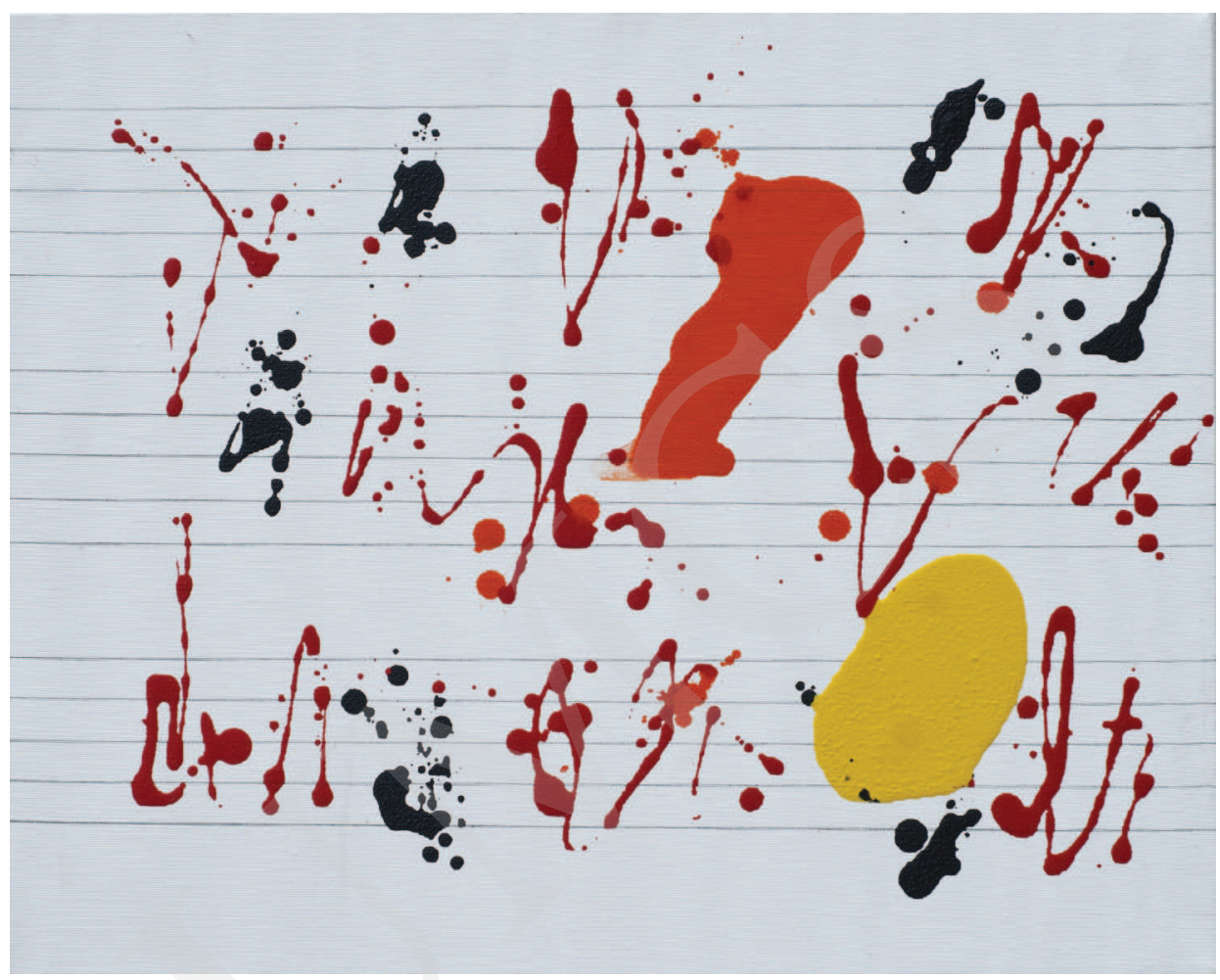

Ilustracja 3. W. Pawlak, Partytura do baletu Sokrates XXXXXXXXXVIII, 2008, 40x50 cm, fot. K. Kuzko 